\title{
CONTRIBUIÇÃO À GEOLOGIA DO PRÉ-CAMBRIANO DA PORÇÃO CENTRAL DE GOIÁS*
}

\author{
ONILDO JOÃO MARINI**, REINHARDT ADOLFO FUCK**, \\ MARGEL AUGUSTE DARDENNE** e ÁLVARO DE FARIA**
}

ABSTRACT Several units of Precambrian rocks have been recognized in Central Goiás. An older group is represented by the Alpine type basic-ultrabasic rocks of the Cana Brava massif and the granodioritic gneisses of Trombas and Montividiu. These rocks are thought to be Archean.

The paragneisses of the Cachoeira das Éguas Formation, the micaschists, the quartzites and the calcschists of the Serra da Mesa Group, as well as the granitic ortogneisses of Serra da Mesa, Serra do Encosto and Serra Dourada, are preliminarily assigned to the Middle Precambrian. The Serra da Mesa Group and the Serra Dourada granite are cut through by several pegmatitic granites of unknown age.

The youngest unit is represented by the Paraopeba Formation of the Upper Precambrian Bambui Group. It comprises phyllite, quartzite and small lenses of calcitic and dolomitic marbles.

The major structural features are formed by the Cana Brava massif - a westward basculated overthrusted block - and the braquianticlines of the Serra Dourada, Serra do Encosto and Serra da Mesa. Other important features are the nearly North-South overthrusts near Trombas and between Serra Dourada and Cana Brava.

INTRODUÇÃo Esta contribuição teve como base inicial os dados geológicos obtidos na execução do Projeto Serra Dourada, realizado por convênio entre a Universidade de Brasília e o Departamento Nacional da Produção Mineral (Marini et al., 1974a). O projeto abrange aproximadamente $3400 \mathrm{~km}^{2}$, situados entre os meridianos $48^{\circ} 15^{\prime}$ e $48^{\circ} 45^{\prime}$ de longitude oeste e os paralelos $13^{\circ}$ e $13^{\circ} 45^{\prime}$ de latitude sul (Fig. 1). A área, dividida nas folhas Mata Azul, Ribeirão Gorrente, Trombas, Serra da Mesa e Serra Dois de Junho

Figura 1 - Localização da área do Projeto Serra Dourada, no centro-oeste brasileiro

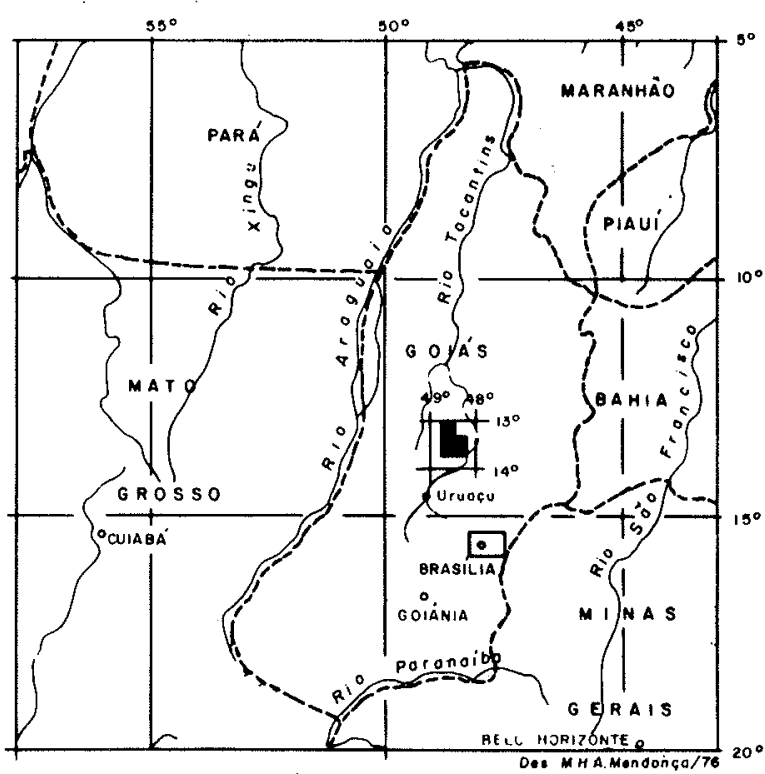

* Síntese e revisão do Projeto Serra Dourada (FUB/DNPM), publicado com autorização do Diretor-Geral do DNPM

**Departamento de Geociências, Universidade de Brasília, 70000 - Brasília - D.F. - Brasil 
(Fig. 2), foi originalmente cartografada em escala 1:50000 (Faria et al., 1974; Dardenne et al., 1974; Fuck et al., 1974; Marini et al., 1974b; e Marini et al., 1974c).

Os trabalhos iniciais do Projeto Serra Dourada foram realizados em 1972, por uma equipe de professores e alunos do Departamento de Geociências da Universidade de Brasília, e deles resultaram dezoito relatórios e mapas geológicos parciais (Relatórios de Graduação), executados por duplas de alunos formandos em Geologia: (Almeida, 1972; Almeida e Silva, 1972; Andrade e Gonçalves, 1972; Barreira e Barbosa, 1972; Barreto Filho e Viana, 1972; Campos Neto e Fráguas, 1972; Coelho Filho e Pereira, 1972; Costa, 1972 ; Ferreira, 1972; Moreno e Rabelo, 1972; Pedroso e Trindade Sobrinho, 1972; Ribeiro e Passos, 1972; Sá e Oliva, 1972; Sadeck e Hecht, 1972; Santiago e Ferreira, 1972; Silva e Vieira, 1972; Souza e Lara Filho, 1972; e Teixeira Neto e Ferreira, 1972).

Coube a Marini et al. (1974a, inédito) a revisão geral de campo e de laboratório, a integração e a uniformização de informações colhidas e a interpretação preliminar da geologia da área do Projeto Serra Dourada. Nesta nota, os autores apresentam uma revisão sintética e formulam novas conceituações sobre a geologia da região.

A área é caracterizada por uma gama grandemente variada de rochas, que, excetuadas as esparsas, finas e pouco extensas coberturas fanerozóicas de origem continental, datadas do Cretácen Superior ao Recente, pertencem ao Pré-Cambriano. Embora a estratigrafia da área seja ainda controvertida sob inúmeros aspectos, é possível separar, com base em evidências litológicas e estruturais, várias unidades geológicas, representadas na coluna estratigráfica da Tab. I, que procura sintetizar as relações estratigráficas e cronogeológicas das unidades aflorantes na região e apresenta seus tipos litológicos mais característicos.

Quanto à idade, os gnaisses granodioríticos e o Complexo Cana Brava aparentemente pertencem ao Pré-Cambriano Inferior (Almeida, 1971): os primeiros, por fazerem parte do complexo granito-gnáissico, que na região de Rubiataba foi datado em 2700 m.a. (Y. Hasui e F. F. M. de Almeida, informação verbal); o segundo, em analogia aos maciços

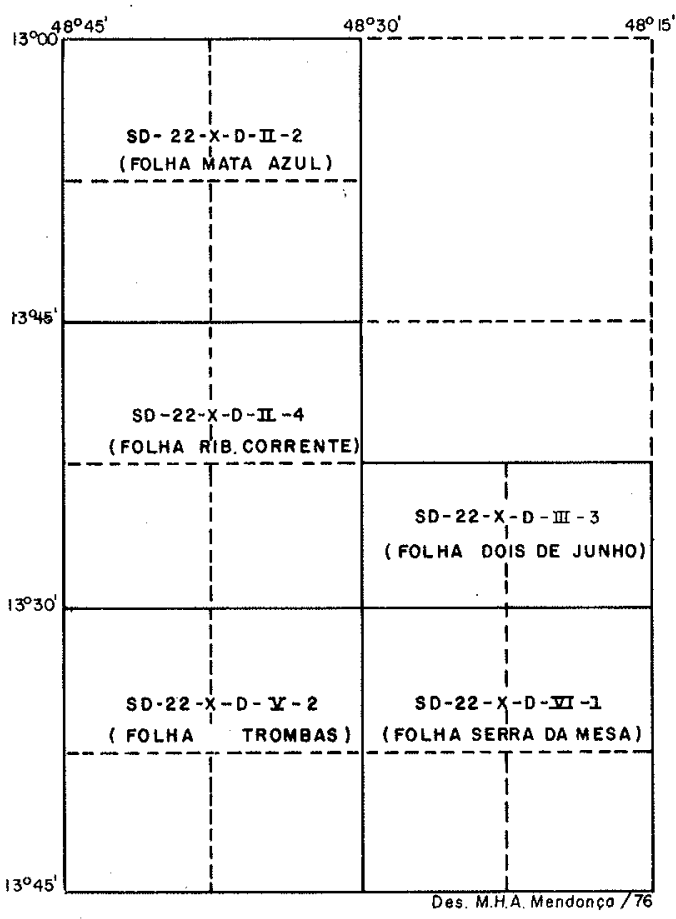

Figura 2 - Articulação das folhas e subáreas do Projeto Serra Dourada 
Tabela I - Coluna estratigráfica geral para a área do Projeto Serra Dourada

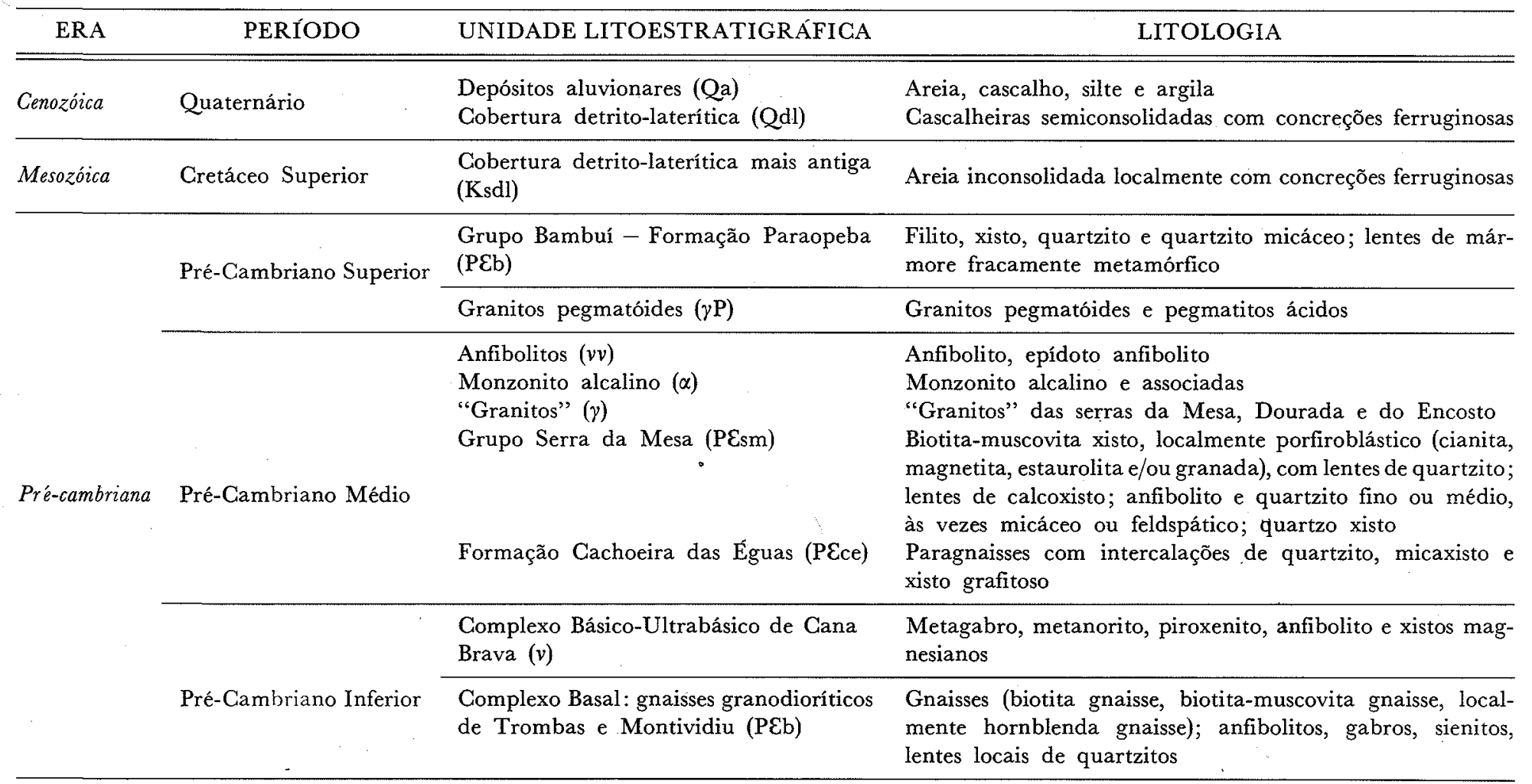


de Barro Alto e Niquelândia, cujas idades são superiores a 3000 m.a. (Cordani e Hasui, in Schobbenhaus Filho et al., 1975). Os gnaisses do Rio Maranhão, os xistos do Grupo Serra da Mesa e os "granitos" das serras da Mesa, Dourada e do Encosto possivelmente são do Pré-Cambriano Médio, enquanto que as demais unidades são atribuídas ao Pré-Cambriano Superior. Saliente-se, porém, que os poucos e esparsos resultados de datações geocronológicas das rochas da região não fornecem ainda suporte suficiente para se estabelecer uma cronoestratigrafia mais acurada e digna de confiança.

Domos e braquianticlinais, com núcleos ocupados por "granitos" foliados, sustentam as serras principais e governam o padrão estrutural geral da região.

O padrão estrutural dos metassedimentos dos grupos Serra da Mesa e Bambuí, em em escala de afloramento, é o de isoclinais fechadas, com vergência para leste.

Importantes falhas de empurrão, com direção geral norte-sul e deslocamento para leste, foram registradas na região de Trombas e entre as serras Dourada e Cana Brava.

O Maciço de Cana Brava apresenta-se como bloco basculado, a oeste, e limitado, a oriente, por importante falha inversa.

Os granitos pegmatóides, o corpo anfibolítico do Filó, bem como os demais anfibolitos e epídoto anfibolitos das vizinhanças são intrusivos no Grupo Serra da Mesa.

Do Fanerozóico, ocorrem somente finas coberturas detrito-lateríticas cretáceas e pleistocênicas, ligadas a superfícies aplainadas, além de aluviões recentes.

A região é rica em ocorrências minerais: amianto, cassiterita, muscovita, barita, berilo, turmalina, fluorita, esmeralda e calcário constituem as mais importantes.

COMPLEXO BASAL GOIANO - GNAISSES GRANODIORÍTICOS DE TROMBAS E MONTIVIDIU A porção ocidental da área estudada é caracterizada por extensões relativamente grandes de afloramentos de gnaisses, entre os quais dominam os biotita gnaisses, e que constituem o embasamento dos xistos e quartzitos do Grupo Serra da Mesa (Fig. 3). As principais ocorrências estão localizadas a oeste de Mata Azul, na região de Montividiu, nas vizinhanças de Trombas, bem como na chamada Serra de Trombas. Ocorrências de menor expressão são esporadicamente encontradas, especialmente nos vales das drenagens principais, como, por exemplo, ao norte da Fazenda Iracema, em um dos afluentes da margem esquerda do Rio Cana Brava.

Trata-se, em geral, de rochas de aspecto granítico ou granodiorítico, de granulação média a grossa, com foliação que varia de difusa e pouco definida até conspícua. Estruturas bandadas são raramente observadas. As texturas são granulares ou porfiroblásticas, localmente oftalmíticas, especialmente em zonas de cataclase mais intensa. Verdadeiros granitos e granodioritos foram observados, porém sua separação tornou-se impraticável, devido à precariedade das exposições e também à gradação entre os diversos tipos petrográficos encontrados.

Os componentes mineralógicos essenciais dos gnaisses são quartzo e plagioclásio (An 20-35\%), aos quais se ajunta a microclina, em proporções variáveis $(0-40 \%)$ e com caráter intersticial, embora possa, como o plagioclásio, constituir fenoblastos. Biotita é o componente máfico mais comum, podendo estar acompanhado de hornblenda, e, ocasionalmente, granada e clinopiroxênio. A muscovita está presente em muitas amostras, sendo porém nitidamente secundária, formada a partir dos feldspatos. Sua presença é mais conspícua em rochas fortemente cataclásticas. Entre os minerais acessórios mais freqüentes, encontram-se zircão, apatita, alanita, titanita, ilmenita, turmalina e rutilo. Dentre os minerais secundários, merecem referência clorita, epídoto e opacos, que resultam da alteração dos máficos, e calcita, sericita e zoisita, formadas a partir do plagioclásio. 


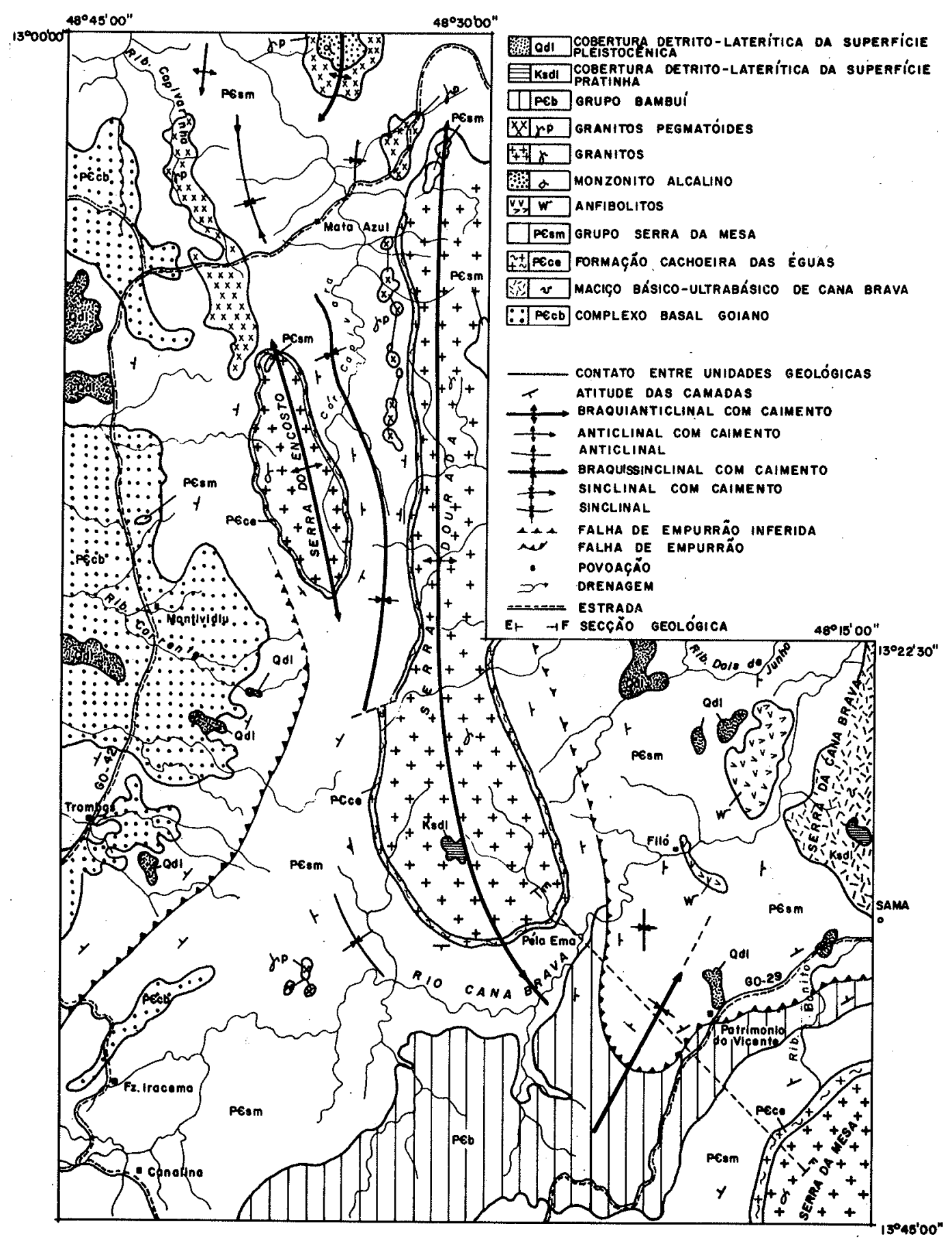

Figura 3 - Esboço das principais unidades geológicas e tectọnicas na área do Projeto Serra Dourada 
Associados a essas rochas, ocorrem, com certa freqüência, pequenos corpos de anfibolitos, lentes de quartzitos, e, ocasionalmente, gnaisses sieníticos, cuja representação não cabe na escala do mapa da Fig. 3. As dimensões dos anfibolitos e quartzitos são reduzidas, raramente excedendo $1000 \mathrm{~m}$ de comprimento e não mais que 20 ou $30 \mathrm{~m}$ de possança. Num dos corpos de anfibolitos, a noroeste de Montividiu, foi encontrado afloramento de hiperito, constituído de labradorita, hiperstênio e augita. O plagioclásio mostra-se saussuritizado e os piroxênios foram parcialmente substituídos por hornblenda. Os gnaisses sieníticos são constituídos de ortoclásio microclinizado e hornblenda contendo restos de clinopiroxênio.

As paragêneses minerais, encontradas nos diversos tipos petrográficos examinados, correspondem a metaformismo do fácies anfibolítico, tendo, pelo menos localmente, sido atingida a zona do ortoclásio, dada a presença de cristais reliquiares desse mineral em algumas amostras.

As estruturas dos gnaisses granodioríticos não são bem-conhecidas, em virtude da ausência de camadas-guia. Entretanto, a direção geral da foliação é nordeste-sudoeste e a vergência, para leste.

A idade dessas rochas não é conhecida com precisão, embora tudo indique tratar-se de um conjunto muito antigo. Fazem parte do Maciço Intermediário Groiano (Costa e Angeiras, 1971), também denominado Maciço Mediano de Goiás (Almeida et al., 1976), visto que se estendem da área estudada para oeste, em direção a Porangatu, e para sudoeste, passando por Formoso, em direção a Rubiataba, Itapuranga, Goiás e Juçara. As determinações de idades radiométricas existentes indicam idade provavelmente superior a 3000 m.a., embora valores menores sejam muito comuns, mostrando que as rochas do maciço foram envolvidas em vários ciclos posteriores de deformação e metamorfismo. Um anfibolito, colhido a sudoeste de Formoso, forneceu idade K/Ar de $2300 \pm 120$ m.a. e um granito-gnaisse, coletado a oeste da mesma cidade, teve como resultado de determinação, pelo método $\mathrm{Rb} / \mathrm{Sr}$, em rocha total, 1510 m.a., com razão iniciąl $\mathrm{Sr}^{87} / \mathrm{Sr}^{86}=$ $=0,708$ (Hasui e Almeida, 1970). Os mesmos autores referem que uma determinação K/Ar em biotita de gnaisse, amostrado em Formoso, forneceu a idade de $483 \pm 15$ m.a. O granitóide de Rubiataba foi datado de 2700 m.a., por Rb/Sr (Y. Hasui e F. F. M. Almeida, informação verbal). Anfibolitos, colhidos ao norte de Ceres, mostram idade $\mathrm{K} /$ Ar de $3700 \pm 220$ m.a. e $2900 \pm 150$ m.a. (Hasui e Almeida, 1970). A partir desses dados esparsos, pode-se inferir que os gnaisses granodioríticos cartografados na região de Montividiu possivelmente pertencem ao Pré-Cambriano Inferior.

COMPLEXO BÁSICO-ULTRABÁSICO DE CANA BRAVA A área do Projeto Serra Dourada inclui cerca de $40 \mathrm{~km}^{2}$ da porção sul-ocidental do Maciço de Cana Brava. Segundo Barbosa et al. (1969), o maciço mede aproximadamente $104 \mathrm{~km}$ de comprimento por $44 \mathrm{~km}$ de largura, estendendo-se desde o Ribeirão Bonito até as cercanias de Porto Real, no Rio Maranhão. Em termos de largura, essas dimensões são exageradas, dado que o limite ocidental do complexo se situa a leste do Rio Cana Brava e não a alguns quilômetros a oeste, como inferido por aqueles autores.

As relações de contato do complexo com as rochas vizinhas não são ainda bem-conhecidas e sua elucidação demandará estudos mais completos em toda a sua extensão. Na área percorrida, o contato está encoberto por depósitos coluviais, não tendo sido possível obter evidências positivas que permitissem identificar as verdadeiras relações entre as rochas básicas e os xistos referidos ao Grupo Serra da Mesa. Indícios de efeitos térmicos não foram observados. Os xistos não mostram estruturas ajustadas ao contorno do maciço e sua xistosidade em geral se inclina para leste na região do contato, ou seja, contra o 
maciço. Não há estrutura dômica, como referido por Almeida (1968). Em vários locais da borda oeste, as rochas básicas apresentam-se cisalhadas e brechadas, indicando a existência de falhas, cuja continuidade, entretanto, não pôde ser confirmada.

A presença de duas faixas descontínuas de gnaisses, na borda oeste do complexo, parece, no entanto, ser significativa. Trata-se de granada-biotita gnaisses, alguns portadores de silimanita e ortoclásio, cuja paragênese indica metamorfismo de grau elevado. Rochas semelhantes, inclusive granulitos, são também encontradas a leste do maciço, no leito do Rio Maranhão. Configura-se, assim, uma situação semelhante à dos maciços de Niquelândia e Barro Alto, onde as rochas básicas é ultrabásicas estão ássociadas a granulitos, anfibolitos e gnaisses de alto grau metamórfico. Tais rochas parecem ser as mais antigas do Planalto Central Brasileiro, a crer-se nas idades K/Ar superiores a 3700 m.a., obtidas por Souza, (1973), em plagioclásio de enderbitos e em anfibólios de anfibolitos coletados no Complexo de Barro Alto. Quanto a Cana Brava, apenas uma determinação em plagioclásio de metagabro foi publicada (Hasui e Almeida, 1970). O valor encontrado, $916 \pm 92$ m.a., possivelmente não indica a idade da rocha e sim seu envolvimento em evento tectônico posterior, talvez relacionado com o Ciclo Uruaçuano, fato aliás confirmado pelos estudos recentes de Matsui et al. (1976).

Outro aspecto controvertido é a estrutura do Maciço de Cana Brava. Para os autores do Projeto Brasília (Barbosa et al., 1969), a área do maciço estaria confinada por um horst que se elevou, por falhas inversas laterais, por sobre as rochas dos grupos Araxá, Bambuí e Araí, e o maciço estaria basculado para norte. Na realização deste trabalho, não foram encontradas evidências que permitissem corroborar essa hipótese. Milewski et al. (1970), baseados em relatório inédito de Miranda Barbosa e Grossi Sad, referem-se a Cana Brava como sendo um lopólito, limitado a oeste por falhamento de empurrão. Para esses autores, trata-se de corpo intrusivo estratiforme, com "diferenciação magmática por cristalização fracionada e deposição mineralógica, sob controle da gravidade e correntes de fluxo".

A suposta existência de serpentinitos, a oeste do maciço, que dava suporte à hipótese da estrutura lopolítica, não foi confirmada pelos trabalhos de campo, executados durante - Projeto Serra Dourada. Ao contrário, as evidências encontradas sugerem tratar-se de um maciço tipo alpino, limitado, a leste, por faixa de blastomilonitos associados a uma extensa falha inversa, inclinada aproximadamente $40^{\circ}$ para oeste (Marini et al., 1976), no mesmo sentido de basculamento do maciço.

$\mathrm{Na}$ área abrangida por este trabalho, o Complexo de Cana Brava foi dividido em duas unidades petrograficamente distintas. A quase-totalidade do corpo compõe-se de rochas de composição norítica a gábrica, que, a sul, são margeadas por estreita faixa de piroxenitos, serpentinitos e xistos magnesianos, que se estendem por grande parte da borda leste do maciço.

As rochas básicas são as mais comuns da Serra de Cana Brava, ocupando a porção superior do maciço. São constituídas essencialmente de plagioclásio (An 50-60\%), clinopiroxênio e ortopiroxênio, os dois últimos em proporções variadas, de sorte que, petrograficamente, as rochas passam de gabros a gabronoritos e a noritos. Em quantidades subordinadas, ocorrem hornblenda, apatita, opacos, granada, quartzo, epídoto, actinolita, talco e clorita. Localmente, a hornblenda assume proporções elevadas, superando os piroxênios. É em geral verde, às vezes castanha, e provém dos piroxênios. A biotita é produto de transformação dos piroxênios e da hornblenda e o talco provém do ortopiroxênio. $\mathrm{O}$ epídoto (membro do grupo das clinozoisitas) resulta da alteração de plagioclásio e máficos. Poucas são as amostras em que não se observam evidências de ação metamórfica. Texturas granoblásticas, evidenciadas por contatos entre grãos de piroxênio e plagioclásio formando ângulos de $120^{\circ}$, foram verificadas em rochas dotadas de bandamento, 
com alternância de faixas claras, ricas em plagioclásio, e escuras, em que dominam os piroxênios. O desenvolvimento de hornblenda, a partir de piroxênios, e o de biotita, a partir de anfibólio e piroxênio, especialmente na borda oeste do complexo, é acompanhado por crescimento subparalelo de minerais e por desenvolvimento de foliação na rocha. A epidotização de plagioclásios e de máficos e a cloritização de piroxênios, de anfibólios e de biotita provavelmente correspondem a transformações mineralógicas de mais baixa temperatura. Aparentemente, essas feições metamórficas se relacionam a várias fases de metamorfismo, uma delas sob condições de fácies granulítico.

Anfibolitos ocorrem, com certa freqüência, na parte oeste do maciço, associados aos metagabros, metagabronoritos e metanoritos. Compõem-se do par hornblenda verde-plagioclásio (An 50-55\%), tendo como minerais subordinados clinopiroxênio, quartzo, titanita, opacos, epídoto e granada, esta ocasionalmente presente sob a forma de cristais centimétricos poiquiloblásticos.

A porção sul do maciço compõe-se sobretudo de rochas piroxeníticas, em sua extensão maior transformadas em xistos magnesianos e serpentinitos. Compõem-se os piroxenitos de ortopiroxênio (enstatita-bronzita) e clinopiroxênio (diopsídio-salita) em proporções variadas, ora predominando um, ora outro. Domina a textura granular xenomórfica e ângulos de $120^{\circ}$, entre contornos de minerais, são observados, o que pode ser indicação de recristalização metamórfica. A presença de hornblenda marrom e de tremolita-actinolita é comum e é devida à transformação dos piroxênios. Subordinadamente, observam-se opacos, plagioclásio, titanita, clinozoisita e serpentina.

A rocha predominante, nessa parte do maciço, aparentemente é o serpentinito, no qual, como acessórios à lizardita, mineral dominante observam-se clorita, talco, carbonato, pleonasto, cromita, magnetita, cristais reliquiares de olivina e piroxênios, especialmente enstatita. Localmente, ocorrem finos veios de crisotila, que, nas áreas mineralizadas, na porção sudeste do maciço, podem constituir mais que $5 \%$ da rocha. V. A. V. Girardi (comunicação pessoal) refere a presença de rodingitos associados aos serpentinitos. Aparecem sob a forma de veios e são constituídos por dolomita e/ou magnesita, por vezes associadas a grossulária, vesuvianita, zoisita, clinozoisita, prehnita, clorita, diopsídio e apatita.

Xistos magnesianos predominam no extremo sul do maciço, ocorrendo entre as ultrabásicas e serpentinitos e as rochas encaixantes. São constituídos de talco, clorita e tremolita, além de magnetita e titanita. As texturas são lepidoblásticas e diablásticas, por vezes porfiroblásticas, em virtude da presença de cristais mais desenvolvidos de clorita ou tremolita.

FORMAÇÃO GACHOEIRA DAS ÉGUAS Essa denominação foi proposta por Marini et al. (1976), para designar uma camada de paragnaisses que circunscreve o corpo de rochas graníticas da Serra da Mesa. Os paragnaisses constituem uma faixa anelar, de largura variável entre 1 e $3 \mathrm{~km}$, com espessura aparente máxima estimada em $1000 \mathrm{~m}$, e cuja foliação mostra mergulhos centrífugos da ordem de 30-50\%. Embora sejam encontrados em toda volta da serra, as melhores exposições foram observadas nos córregos Batéia e Buriti e no leito do Rio Maranhão, onde são responsáveis por trechos encachoeirados, dentre os quais se destaca o que é conhecido por Gachoeira das Éguas pela população local. A camada possui identidade petrográfica própria e é claramente distinguida das rochas vizinhas, tanto no terreno, quanto em aerofotos, sendo, pois, facilmente mapeável.

Os gnaisses são a litologia dominante da formação. Têm granulação variada, em geral média, e, localmente, são porfiroblásticos. Compõem-se de plagioclásio (An 20-25\%), quartzo, microclina, muscovita, biotita, hornblenda e granada, aparecendo zircão sub- 
arredondado, turmalina, apatita, epídoto e opacos como minerais acessórios. Possuem marcante foliação que permite distingui-los com facilidade do "granito".

Intercalações pouco espessas (raramente excedendo $1 \mathrm{~m}$ ) de quartzitos micáceos, xistos grafitosos e biotita xistos são relativamente freqüentes, atestando a origem sedimentar do pacote.

A Formação Gachoeira das Éguas é uma unidade homogênea que não comporta subdivisões estratigráficas. Como localidade- e seção-tipo, Marini et al. (1976) elegeram a boída sul da Serra da Mesa e o leito do Rio Maranhão, na cachoeira que deu o nome à formação, respectivamente.

O contato com as rochas graníticas é brusco. Em vários locais, foi observado que estas contêm xenólitos de gnaisses, biotita xistos e xistos grafitosos, fato que permite inferir o caráter intrusivo do "granito" na formação. Estudos mais detalhados são necessários para confirmar essa hipótese, ou a de reomorfismo, aventada por Barbosa et al. (1969), quando sugeriram tratar-se de domos manteados, as estruturas braquianticlinais da região.

O contato superior é igualmente brusco, assentando-se diretamente sobre os paragnaisses da camada de quartzito, que é considerada basal do Grupo Serra da Mesa. A quebra litológica é nítida, embora o acamamento do quartzito e a foliação dos gnaisses sejam paralelos. Não foram encontradas indicações de ciclo erosivo entre as duas camadas, existindo, pois, a possibilidade de os paragnaisses constituírem a porção basal do referido grupo.

Rochas semelhantes e provavelmente correlativas ocorrem em volta dos "granitos" Serra Dourada e Serra do Encosto, onde, no entanto, aparecem em faixas mais estreitas e descontínuas. Distinguem-se, também, com facilidade, da massa granítica que compõe o núcleo dessas serras, por sua granulação mais fina e foliação mais acentuada, que, com certa freqüência, dá lugar a bandamento gnáissico.

A idade da formação não é conhecida. A crer em determinações $\mathrm{Rb} / \mathrm{Sr}$ recentes, obtidas por Y. Hasui (comunicação verbal) em amostras do "Granito". Serra da Mesa, que forneceram valores da ordem de 2000 m.a., os paragnaisses seriam do Pré-Cambriano Médio.

Do ponto de vista econômico, as faixas de gnaisses que circunscrevem os corpos graníticos revestem-se de amplo interesse. Todas elas são recortadas por filões pegmatíticos portadores de feldspato, quartzo, muscovita, berilo, topázio, água marinha e turmalina. Além disso, na borda sul da Serra Dourada, ocorrem massas biotíticas que parecem ser a fonte primária da cassiterita descoberta na região. Na mesma área, vem sendo explorada interessante ocorrência de esmeralda (Garimpo do Péla-Ema), associada a rochas "verdes" contidas nos paragnaisses.

GRUPO SERRA DA MESA Apresentação Os xistos e rochas associadas de fácies anfibolítico da área têm sido até o momento incluídos no Grupo Araxá. Esse grupo foi inicialmente definido por Barbosa (1955) como um "complexo metamórfico pré-cambriano, constituído de micaxistos, xistos verdes, filitos, migmatitos e quartzitos", descritos no Planalto de Araxá, em Minas Gerais. Em caráter provisório, o autor mencionado dividia o "complexo" em duas formações que denominou Araxá e Canastra, separadas entre si provavelmente por discordância angular. Segundo Barbosa (1955), a Formação Araxá ocuparia a bacia do Rio Quebra-Anzol, de onde se estende para norte, alcançando o Rio Paranaíba e seguindo Goiás adentro. Em trabalhos posteriores, Barbosa e colaboradores utilizaram a denominação Araxá para designar conjuntos de xistos, que cartografaram em vastas áreas na porção central de Goiás e mesmo no Sul do Pará. Nesses trabalhos, 
essa unidade foi caracterizada primeiramente como série, e, finalmente, como grupo (Barbosa, 1963, inédito; Barbosa et al., 1966; 1969; 1970a; 1970b).

Dos trabalhos realizados pela PROSPEG S.A., para o Departamento Nacional da Produção Mineral, no contexto do Projeto Brasília (Barbosa et al., 1969), resultou que micaxistos, quartzitos e calcoxistos aflorantes na área estudada foram incluídos no Grupo Araxá. Entretanto, em 1970b, Barbosa et al. já observaram a marcante diferença em conteúdo litológico e em características tẹctônicas, ao referirem a sedimentação da região de Araxá como dominantemente pelítica e desprovida de rochas calcárias e efusivas, enquanto que a do centro de Goiás seria caracterizada por abundantes e espessos quartzitos na base e rochas calcárias no topo, intercalados nos metapelitos, bem como pela presença de rochas básicas e ultrabásicas.

No pacote metassedimentar da região de Araxá, Barbosa et al. (1970b) identificaram condições miogeossinclinais de sedimentação e deformação. Já a região central de Goiás, haviam interpretado de forma distinta, atribuindo a ela evolução eugeossinclinal (Barbosa et al., 1969).

Tais colocações, somadas a novos elementos sobre a geologia da região, e, em particular, o melhor conhecimento da estratigrafia e da tectônica do centro de Goiás, permitem contestar a correlação de seus metamorfitos com os metassedimentos do Planalto de Araxá.

O principal critério que tem levado à inclusão de pacotes metassedimentares de Goiás no Grupo Araxá tem sido o grau metamórfico, desprezando-se praticamente sua estratigrafia, principal critério válido e aceito para correlação em terrenos pré-cambrianos. No conceito vigente, só o fato de uma seqüência conter micaxistos tem sido razão suficiente para enquadrá-la no referido grupo. Por outro lado, sequiências com metamorfismo menos acentuado são sumariamente eliminadas do Grupo Araxá e incluídas em unidades diversas como Canastra, Araí, Natividade, Ibiá e Bambuí.

Apesar de os trabalhos de Barbosa e colaboradores terem mostrado uma certa continuidade dos micaxistos desde o Triângulo Mineiro até a área em discussão, merece atenção especial a quebra estrutural cartografada na região de Pirenópolis (Barbosa et al., 1970a; Costa e Angeiras, 1971; Lindenmayer, 1972; Schobbenhaus et al., 1975).

Almeida et al. (1976) inferiram um lineamento de direção N60W, na citada região, separando um bloco sul em que as estruturas são de direção $\mathrm{N} 45 \mathrm{~W}$, tendendo a $\mathrm{N} 60 \mathrm{~W}$ e aproximando-se de E-W ao norte de Corumbá de Goiás, em contraste com o bloco norte, onde as estruturas têm direção geral NNW-SSE, aproximando-se de N-S na região do "Granito" Serra Dourada, passando para NE-SW próximo à Serra da Mesa.

Ainda não é conhecida a natureza desse lineamento, nem sua significação estrutural. É provável que essas mudanças estruturais indiquem cinturões orogenéticos distintos, sendo o do norte de idade mais antiga que o Grupo Araxá, que ocorre no Triângulo Mineiro e no sul de Goiás.

Os dados geocronológicos atualmente disponíveis sugerem que o Grupo Araxá teria se formado e metamorfizado durante o chamado Ciclo Uruaçuano (Almeida, 1967a, 1968), entre 1100 e 1400 m.a. (Hasui e Almeida, 1970; Almeida, 1971; Almeida et al., 1976). Entretanto há indicações de que pelo menos parte das litologias que vêm sendo consideradas como Araxá pertencem, na realidade, a um ciclo tectorogenético mais antigo, referente ao Transamazônico (cerca de 2000 m.a.), conforme assinalam Gordani e Hasui (in Schobbenhaus et al., 1975), na discussão de dados geocronológicos obtidos por Souza (1973), a partir de amostras coletadas na região de Ceres. Assim, é mais provável que os metassedimentos de fácies anfibolítico, que cobrem cerca de $2000 \mathrm{~km}^{2}$ da área estudada no presente trabalho, não pertençam ao Grupo Araxá, mas constituam unidare provavelmente mais antiga, de idade transamazônica. 
Como trabalhos recentes mantêm, para o Grupo Araxá, sensu stricto idade de aproximadamente 1100 m.a. (Almeida et al., 1976) e dados preliminares indicam, para os xistos da porção central de Goiás, aproximadamente 2000 m.a. (Cordani e Hasui, in Schobbenhaus et al., 1975), não vêem os autores sentido em manter para estes a denominação Araxá. Considerando que é, na área discutida neste trabalho, em especial na região da Serra da Mesa, que está preservada a seção mais completa de xistos e de rochas associadas na porção central do Estado de Goiás (Barbosa et al., 1969), propõem os autores que se passe a denominá-la de Grupo Serra da Mesa, tendo como seção-tipo a borda oeste da serra do mesmo nome, discutida nesta contribuição.

Estrutura Na área estudada, a direção geral dos metassedimentos Serra da Mesa é próxima de N-S, freqüentemente infletindo para NNW-SSE (folhas Mata Azul, Trombas e Dois de Junho) ou para NE-SW (Serra da Mesa e a sudeste de Trombas). A feição estrutural que caracteriza a macroestrutura da área é constituída pelos braquianticlinais das serras da Mesa, Dourada e do Encosto, nas quais os metassedimentos se dispõem na forma de envoltório, circunscrevendo os paragnaisses e "granitos" que compõem o núcleo das serras. Nessas estruturas, a direção e o mergulho do acamamento e da xistosidade são centrífugos, a partir da porção central, e, nas terminações periclinais, a orientação é anômala, em relação às estruturas regionais (Fig. 3). Esses fatos mostram a origem tardia dos braquianticlinais, que resultaram de superimposição tectônica, e podem inclusive estar relacionados a eventos do Ciclo Brasiliano.

Estrutura semelhante está delineada em relação às rochas alcalinas, onde xistos e quartzitos mostram disposição igualmente periclinal, na extremidade norte da Folha Mata Azul.

Entre os altos modelados pelos braquianticlinais, ocorrem depressões estruturais em forma de bacias ou de sinclinórios (Figs. 3 e 4), onde se acha preservada espessa seqüencia do Grupo Serra da Mesa. A maior dessas depressões é a que se situa entre as serras da Mesa e Dourada, onde o desnível, inferido por reconstrução geométrica, entre o topo e a base do pacote de camadas Serra da Mesa é de, no mínimo, $1850 \mathrm{~m}$ (Fig. 4). Essa reconstrução estrutural, descontadas as camadas repetidas por tectonismo, é o único critério para se estimar a espessura, ainda que aparente, dos metassedimentos na região, em vista de seu forte redobramento interno.

Ainda em relação às macroestruturas, cabe assinalar o anticlinório na porção central da Folha Trombas, seguido, em direção oeste, por sinclinais e anticlinais, alguns com flancos invertidos, como no Morro dos Cavalos.

A mesoestrutura e a microestrutura dos metamorfitos é tipicamente de isoclinais de flancos apertados, muito embora as mesmas sejam dificeis de identificar, na maioria das exposições. Glivagem de crenulação é comum, embora não seja muito acentuada, por isso mesmo mais fácil de reconhecer $\mathrm{em}$ seções delgadas.

Estratigrafia Barbosa et al. (1969) dividiram os metassedimentos da região, então atribuídos ao Araxá, em duas unidades: Unidade $A$, mais antiga, que compõe-se de micaxistos com granada, estaurolita, cianita, cordierita ( $\mathrm{sic}$ ), com intercalações de quartzitos, xistos grafitosos e anfibólio xistos, e Unidade $B$, que consiste em calcoxistos, com intercalações de calcários, rochas básicas e ultrabásicas, granitos, granodioritos, tonalitos e sienitos alcalinos. A inclusão de rochas ácidas, básicas, ultrabásicas e alcalinas nessa unidade não parece apropriada, de um lado por serem rochas plutônicas e de outro por possuírem idades controvertidas. Assim, a Unidade B deve ficar restrita aos calcoxistos, mármores

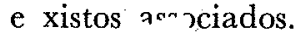




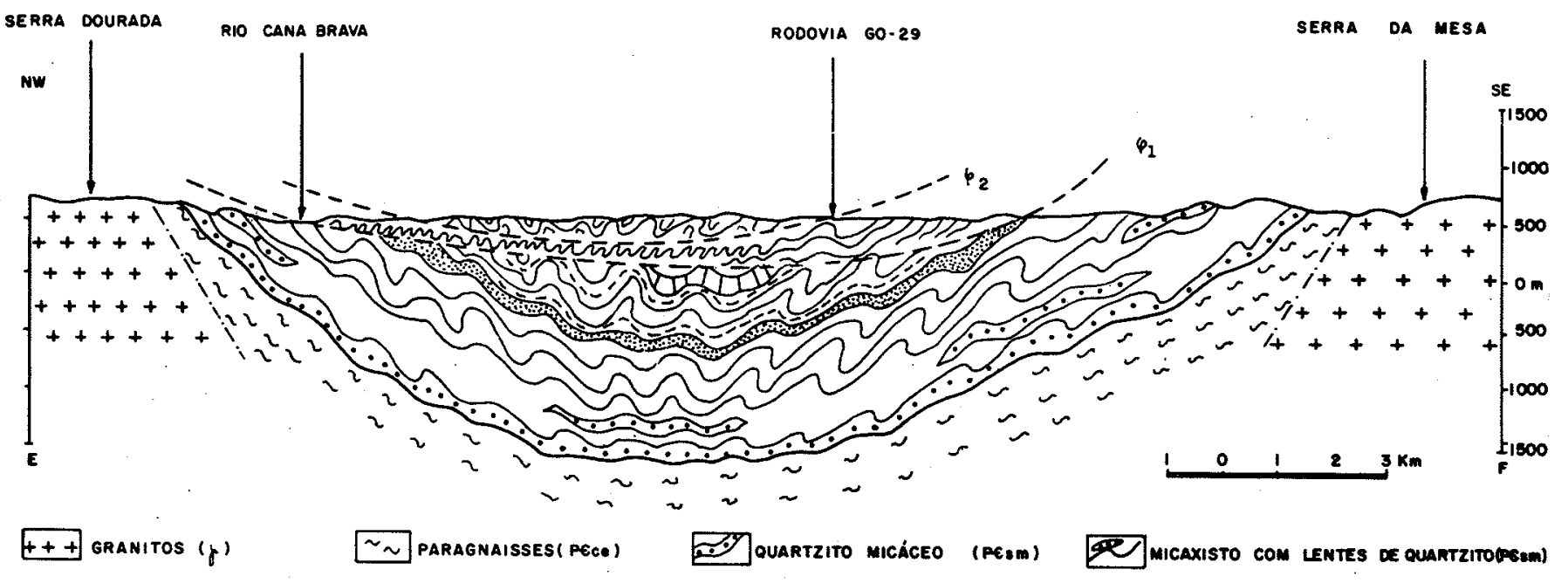

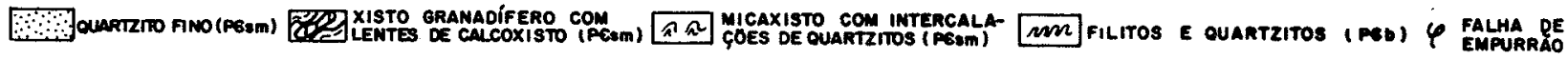

Figura 4 - Seção geológica esquemática na Folha Serra da Mesa 
À Unidade A pertence a maior parte dos metassedimentos Serra da Mesa encontrados na área. Estes não apresentam rochas portadoras de cordierita, sendo, ao contrário, caracterizados por metamorfismo do tipo barroviano. A unidade é dominantemente constituída por quartzitos e xistos, sendo a porção inferior caracterizada por xistos com freqüentes e espessas intercalações de quartzitos; na porção superior, dominam os muscovita xistos, aparecendo os quartzitos como camadas pouco espessas e não-mapeáveis. A Unidade B é representada pelos calcoxistos e mármores que ocorrem nas folhas Serra da Mesa e Trombas.

O estabelecimento de uma estratigrafia detalhada abrangendo a área toda é dificultado pelas mudanças de fácies petrográficos e sedimentares e, evidentemente, pelas deformações sofridas pelo pacote e que obscurecem o empilhamento original. Entretanto a seção entre a Serra Dourada e a Serra da Mesa é aparentemente uma das mais completas e permite uma visão geral da seqüência aflorante na região estudada (Fig. 5). Da base para o topo, têm-se as camadas descritas a seguir.

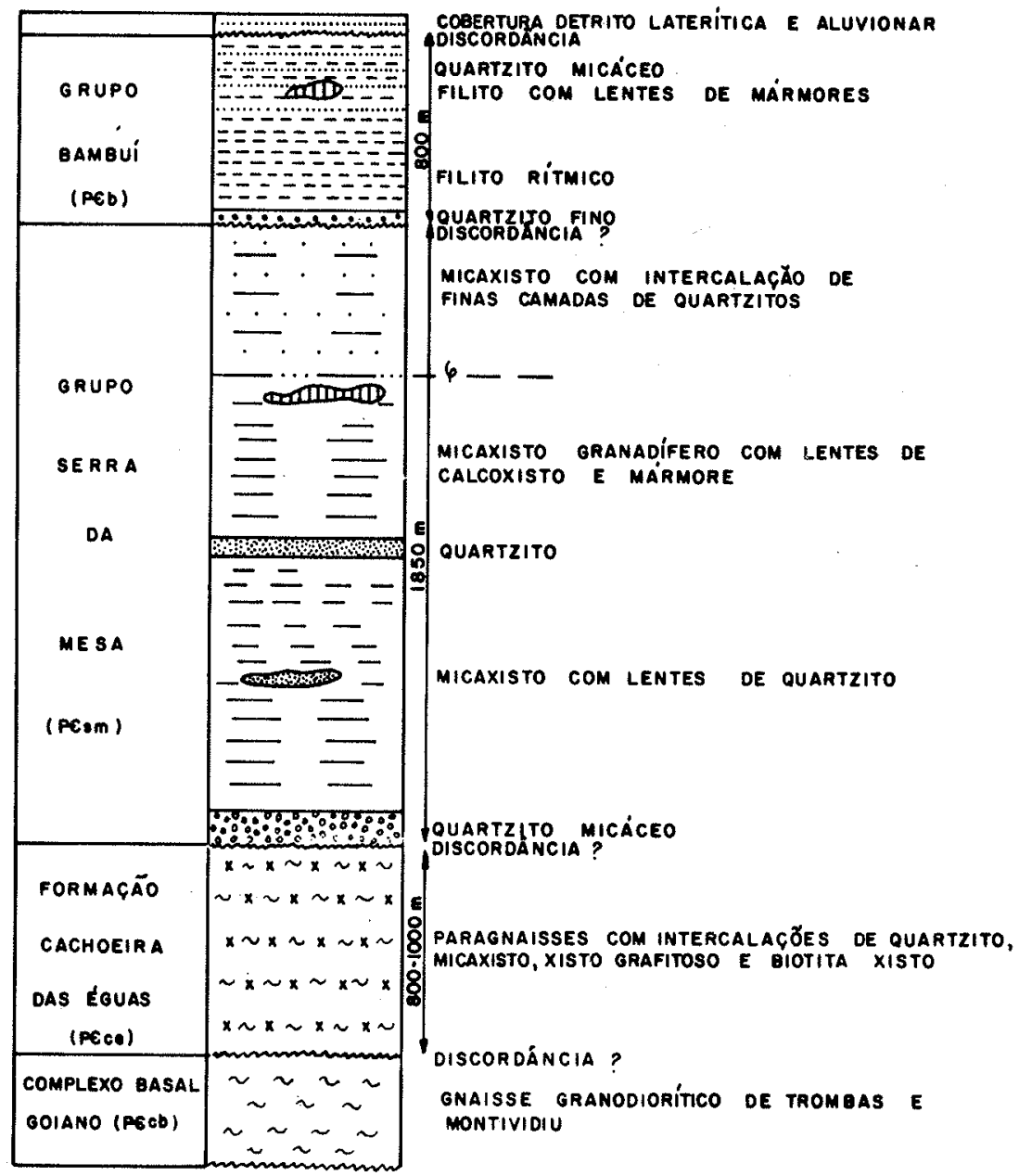

Figura 5 - Coluna estratigráfica composta para a porção sul da área do Projeto Serra Dourada 
Quartzito micáceo Apresenta granulação grossa na base, podendo ser conglomerático. Em direção ao topo, a granulação torna-se fina e a muscovita é abundante, conferindo à rocha um caráter laminado. A camada tem aproximadamente $80 \mathrm{~m}$ de espessura e constitui anel contínuo em todas as estruturas braquianticlinais da área, com acentuado destaque no relevo.

Micaxisto com lentes de quartzito A camada possui aproximadamente $800 \mathrm{~m}$ de espessura e está exposta ao longo de uma faixa de 3 a $5 \mathrm{~km}$ de largura, nos braquianticlinais. Compõe-se de micaxistos localmente com porfiroblastos de granada, estaurolita ou cianita. $\mathrm{Na}$ base, o xisto é mais rico em quartzo e são comuns as intercalações de quartzitos brancos, desde finos a grosseiros, com estratificação planoparalela e espessura inferior a $50 \mathrm{~m}$. Foram notadas, também, intercalações de xisto grafitoso e calcoxisto.

Quartzito A rocha é bem acamada, de granulação fina e média, sendo reduzido o teor de muscovita. A camada mede cerca de $70 \mathrm{~m}$ de espessura e a ela se sobrepõem, tectonicamente, os metamorfitos do Grupo Bambuí, ao norte da Serra da Mesa.

Na região do Córrego Descoberto, próximo ao limite sul da Folha Serra da Mesa, a camada de quartzito referida é sobreposta por granada-biotita-muscovita xisto.

Micaxisto granadífero com lentes de calcoxisto e mármore A camada possui cerca de $500 \mathrm{~m}$ de espessura e é caracterizada pela presença comum de porfiroblastos de granada, com diâmetros por vezes centimétricos, freqüentemente acompanhados de estaurolita ou cianita. Contém intercalações locais de xisto grafitoso. A presença de lentes de calcoxisto e de mármore próximo ao topo é feição típica da camada.

Em vários locais, como ao sul da Serra Dourada e a leste da Serra da Mesa (Marini et al., 1976), o quartzito sotoposto mostra-se descontínuo, em razão do que o micaxisto granadífero se funde com o micaxisto com lentes de quartzito.

Micaxistos com intercalações delgadas de quartzito Essa camada ocorre entre a Serra Dourada e a Serra de Cana Brava, estando bem exposta na área da Folha Dois de Junho, ao norte do povoado do Filó. Compõem-na xistos cinza-claros, relativamente finos, intensamente microdobrados, em que a muscovita domina amplamente sobre a biotita. Muscovita-quartzo xistos são freqüentes, bem como intercalações de quartzitos finos, micáceos, às vezes feldspáticos, cuja espessura raramente ultrapassa alguns metros. Essas rochas diferem petrograficamente dos demais xistos e têm-se dúvidas se realmente pertencem ao Grupo Serra da Mesa. Cabe ressaltar que as mesmas constituem o segmento de metamorfitos que se sobrepõe tectonicamente ao Grupo Bambuí, a sudoeste da Serra de Cana Brava. Aparentemente jazem também tectonicamente sobre os micaxistos granadíferos, a leste da Serra Dourada, onde o traço da falha de empurrão inflete para norte (Fig. 3). A camada e suas relações com as demais rochas do Grupo Serra da Mesa e as básico-ultrabásicas do Complexo de Cana Brava carecem de estudo mais pormenorizado. Ressalte-se que a camada contém numerosos corpos anfibolíticos, ausentes das demais.

Metamorfismo Os metamorfitos que integram o Grupo Serra da Mesa exibem condições de metamorfismo correspondentes ao fácies anfibolítico. As paragêneses muscovita-biotita-quartzo-almandina-estaurolita, muscovita-biotita-quartzo-oligoclásio-almandina, muscovita-biotita-quartzo-almandina-ciani ta-oligoclásio, hornblenda-andesina-epídoto, hornblenda-diopsídio-calcita-quartzo-microclina-andesina, epídoto-biotita-hornblenda-calcita-andesina, comumente encontradas na área estudada, são todas típicas desse fácies. 
A presença de cianita indica provavelmente que o metamorfismo foi do tipo barroviano, mas, na realidade, os estudos são ainda insuficientes para a cabal demonstração desse fato. Por outro lado, não foi obtido ainda um padrão de distribuição das paragêneses que permitisse indicar gradientes de pressão e de temperatura nas condições de metamorfismo. A análise preliminar e obviamente superficial das associações mineralógicas encontradas em toda a vasta área de distribuição dos metamorfitos Serra da Mesa, na região do Projeto Serra Dourada, parece indicar condições uniformes de metamorfismo.

A estaurolita é encontrada em toda a área, indicando que sua presença está condicionada tão somente a uma composição química apropriada da rocha, o que poderia corresponder à inexistência de gradientes de $P$ e $T$. Essa inferência é corroborada pelo fato de que a presença de cianita não obedece a um padrão óbvio, tendo sido detetada em afloramentos muito próximos de outros em que se observa estaurolita, parecendo, dessa forma, igualmente condicionada à composição química apropriada. $O$ assunto merece estudos mineralógicos e petrogenéticos mais aprofundados.

Em toda a área, são comumente observadas feições de superimposição metamórfica que resultaram de recristalizações parciais ou generalizadas, com neoformação de muscovita, clorita, biotita e quartzo. Essa recristalização provavelmente é reflexo de eventos do Giclo Brasiliano, razão pela qual as idades radiométricas $\mathrm{K} / \mathrm{Ar}$ obtidas a partir de micas das rochas do Grupo Serra da Mesa oscilam entre 480 a 600 m.a.

As feições de retromorfismo são mais conspícuas nos metamorfitos que ocorrem ao norte do povoado do Filó, os quais, em razão disso, revestem-se de características distintivas, por apresentarem granulação mais fina e associações mineralógicas indicativas de condições menos enérgicas de metamorfismo, embora restos de estaurolita e granada, em antigos cristais pseudomorfizados por sericita, clorita, quartzo e hidróxidos de ferro, permitam inferir metamorfismo original no fácies anfibolítico.

ANFIBOLITOS E ANFIBÓLIO XISTOS Anfibolitos e anfibólio xistos são relativamente comuns na extensa área de afloramentos do Grupo Serra da Mesa. Entretanto poucas ocorrências podem ser representadas na escala adotada, em virtude das dimensões reduzidas dos corpos, em geral assemelhando-se a pequenos diques ou sills intrometidos nos pelitos e metamorfizados junto com os mesmos. A maior incidência de anfibolitos foi notada na região do Patrimônio do Filó (Fig. 3). Ao norte desse povoado, foi verificada a ocorrência maior, com cerca de $20 \mathrm{~km}^{2}$ de afloramentos. Esse corpo aparentemente é um antigo stock de natureza gabróica introduzido nos xistos antes do metamorfismo regional, uma vez que também foi extensivamente metamorfizado. Não são conhecidas suas relações com o Maciço de Cana Brava, situado a leste, a pequena distância, não se podendo excluir a priori a possibilidade de serem contemporâneos e mesmo cogenéticos. A rocha compõe-se do par andesina (An 35-50\%) e hornblenda verde, arranjados em textura nematoblástica. Em algumas amostras, são observados vestígios de textura ígnea, bem como cristais reliquiares de clinopiroxênio envolvidos pela hornblenda. Quartzo intersticial pode estar presente. $\mathrm{O}$ epídoto em alguns exemplares se apresenta como mineral essencial, representado por pistacita e clinozoisita, formadas a partir do anfibólio e do plagioclásio, ocasionalmente pseudomorfizados por inteiro. Apatita, titanita e ilmenita, esta usualmente envolvida por bainha de titanita, são os acessórios mais comuns.

Anfibólio xistos foram verificados em pequeno número de ocorrências, merecendo referência aquelas encontradas junto à Serra de Trombas e a leste do Patrimônio do Filó. Compõem-se de tremolita-actinolita ou hornblenda, acompanhadas de quartzo, de epídoto, de clorita e de minerais opacos, em quantidades variáveis. 
ROCHAS GRANÍTICAS As rochas graníticas que afloram na área do Projeto Serra Dourada constituem feições peculiares no contexto geológico regional. Ocupam a porção central das serras da Mesa, Dourada e do Encosto (Fig. 3), que, ao lado da Serra de Cana Brava, compõem as formas mais características do relevo da região.

Os granitóides são circunscritos por metassedimentos que a eles se amoldam, formando típicas estruturas braquianticlinais, orientadas submeridianamente. Barbosa et al. (1969) descreveram essas estruturas como domos manteados, considerando as rochas graníticas como produto de remobilização do embasamento antigo e os metamorfitos envolventes como integrantes do Grupo Araxá.

Como característica comum, os três corpos são formados por rochas em geral foliadas, especialmente nas bordas dos maciços, tendendo a foliação a se tornar difusa em sua porção central.

As relações de contato dos corpos graníticos com as encaixantes não puderam ser devidamente esclarecidas na área estudada. No entanto, a presença de xenólitos de gnaisses e xistos notados na Serra da Mesa e na Serra Dourada depõe por seu caráter intrusivo.

Quanto à idade desses "granitos", são poucas as informações disponíveis, e mesmo estas possuem valor interpretativo controvertido. Hasui e Almeida (1970) referem valores $\mathrm{Rb} / \mathrm{Sr}$ de 1330 m.a. e K/Ar de $530 \pm 16$ m.a. (em biotita), obtidos em amostras da Serra da Mesa. Dados preliminares obtidos por Y. Hasui (informação verbal), em amostras provenientes do mesmo "granito", parecem indicar idade mais antiga, da ordem de 2000 m.a., que poderia corresponder à idade de formação da rocha, enquanto os valores menores indicariam seu envolvimento em episódios térmicos posteriores, o último dos quais relativo ao Ciclo Brasiliano.

"Granito" Serra da Mesa A porção central da Serra da Mesa é ocupada por uma rocha granítica, em geral foliada, dada a orientação preferencial dos minerais componentes, donde se pode denominá-la de ortognaisse. A granulação é predominantemente média e a cor é rósea-clara ou mesmo branca, destacando-se, nesse fundo claro, as manchas negras dos cristais de biotita. Nas lâminas delgadas examinadas, a microclina sempre domina o plagioclásio (An 20-28\%). A composição modal média é microclina $50 \%$, quartzo $25 \%$, plagioclásio $20 \%$, restando $5 \%$ para biotita e, ocasionalmente, hornblenda, além dos acessórios zircão, cassiterita, turmalina, titanita, alanita, apatita e opacos. Filões pegmatíticos quartzo-feldspáticos portadores de amazonita, ametista, topázio, berilo e columbita-tantalita são comuns. Localmente, observam-se xenólitos de gnaisses e xistos, alguns dos quais grafitosos.

"Granito" Serra Dourada A rocha granítica que constitui a massa principal da Serra Dourada é também um ortognaisse. A granulação é variável, mas em geral dominam texturas grossas, em que quartzo e feldspatos têm dimensões em torno de $1 \mathrm{~cm}$. A microclina é o mineral dominante, seguindo-lhe quartzo e oligoclásio (An 25\%). A rocha é em geral de cor rósea, com manchas pretas de lamelas de biotita, cuja disposição orientada resulta em foliação conspícua. Localmente ocorrem, no interior da serra, gnaisses bandados com estrutura migmatítica, como no Córrego Retiro e a leste da Fazenda Raimundinho (Folha Mata Azul). Restos de xistos são observados na porção leste e também na extremidade norte do "granito". Anfibolitos são encontrados esporadicamente e representam provavelmente antigos diques básicos metamorfizados, indicando que o núcleo granítico foi afetado por pelo menos uma fase de metamorfismo.

"Granito" Serra do Encosto O "Granito" Serra do Encosto possui forma elíptica, cujo eixo maior mede $16 \mathrm{~km}$ e se orienta segundo N20W. Petrograficamente é também um 
ortognaisse, em tudo semelhante ao da Serra Dourada. É róseo e tem granulação grossa, apresentando-se bem foliado. Cortam-no filões aplíticos e pegmatíticos e são comuns xenólitos de biotita xisto com "olhos" de quartzo, semelhantes aos que contêm cassiterita, no garimpo Péla-Ema, na extremidade sul da Serra Dourada.

ROCHAS ALCALINAS Apenas cerca de $1 \mathrm{~km}^{2}$ da extremidade sul da "rocha alcalina da Folha de Peixe", como foi denominada por Barbosa et al. (1969), está compreendida na área estudada (Fig. 3), de sorte que muito pouco se pode adiantar sobre esse conjunto de rochas, neste trabalho. Segundo os autores mencionados, as rochas alcalinas, entre as quais dominaria um litchfieldito, estariam encaixadas em biotita gnaisses bandados e sobrepostas pelos xistos do Grupo Araxá, a oeste. Ainda segundo esses autores, o corpo teria aproximadamente $30 \mathrm{~km}$ de comprimento, dispondo-se segundo direção próxima de N-S.

$\mathrm{Na}$ área abrangida por este trabalho, a rocha alcalina está envolvida por granito pegmatóide, fato esse que, no momento, veda considerações quanto a sua posição na estratigrafia regional. As lâminas delgadas de amostras provenientes da extremidade sul do corpo alcalino permitem classificar a rocha como um monzonito nefelínico (Streckeisen, 1967). A rocha é leucocrática, algo foliada, com textura granular média e fina. Plagioclásio e microclina, em teores aproximadamente iguais, perfazem cerca de $80-90 \%$; os minerais subessenciais são biotita esverdeada (5-10\%) e nefelina (3-7\%), e entre os acessórios destacam-se muscovita, cancrinita, zircão, epídoto, calcita e zeolitas. Filões pegmatíticos são comuns e compõem-se de quartzo, microclina, biotita, hornblenda, coríndon, zircão, ilmenita e afrisita.

O corpo está a merecer um estudo mais completo, dadas as perspectivas de encerrar depósitos minerais de valor econômico (zirconita, coríndon, grafita, etc.).

GRANITOS PEGMATÓIDES Além dos ortognaisses de composição granítica que compõem o núcleo das serras da Mesa, Dourada e do Encosto, outras rochas graníticas são encontradas na área do Projeto Serra Dourada. Os corpos em geral têm formas amebóides e dimensões reduzidas, com exceção de três que são mais extensos: um perlonga por cerca de $22 \mathrm{~km}$ o vale do Córrego Capivarinha, outro envolve as rochas alcalinas no norte da área e o terceiro ocorre junto ao limite noroeste do "Granito" Serra Dourada. A maior parte dos corpos menores constitui espécie de rosário, ao ocidente desse granito, em especial na área abrangida pela Folha Mata Azul (Fig. 3). Alguns desses corpos foram também assinalados na Serra de Trombas e ao norte do Rio Cana Brava (Folha Trombas).

A presença de inúmeros blocos de xistos e quartzitos englobados pelos granitos pegmatóides, sobretudo junto ao contato, confere-lhes um típico caráter intrusivo, tanto nos metassedimentos do Grupo Serra da Mesa, quanto no "Granito" Serra Dourada.

A feição distintiva desses granitóides é sua textura pegmatítica e a granulação gigante. Os minerais componentes são principalmente quartzo, em geral com aspecto leitoso, e microclina pertítica de cor branca ou rósea-clara, cujos cristais medem entre 2 e $5 \mathrm{~cm}$, mas que, não-raro, atingem $30 \mathrm{~cm}$ de comprimento. Em menor proporção, ocorrem oligoclásio e muscovita, esta com hábito radiado ou na forma de lamelas com diâmetros por vezes superiores a $25 \mathrm{~cm}$. Outros minerais comumente presentes são turmalina, berilo, granada, biotita e tantalita.

GRUPO BAMBUÍ - FORMAÇÃO PARAOPEBA Apresentação Os metassedimentos epimetamórficos que afloram na porção sul da área do Projeto Serra Dourada, nas folhas Trombas e Serra da Mesa, foram incluídos por Barbosa et al. (1969) na Formação Paraopeba 
do Grupo Bambuí. A geologia local não fornece elementos para discutir a propriedade dessa caracterização, dado que o trabalho daqueles autores se refere a região muito mais extensa, tendo os mesmos verificado a continuidade de afloramentos da formação desde a região de Brasília. Na verdade, do ponto de vista puramente sedimentológico e estrutural, os epimetamorfitos da área guardam notáveis semelhanças com as bem conhecidas exposições do Bambuí, no Distrito Federal e adjacências. Entretanto a paragênese metamórfica é distinta, visto que a biotita é mineral comumente presente nos filitos, indicando temperatura de metamorfismo mais elevada que no restante da Bacia Bambuí, mais a leste.

$\mathrm{Na}$ área do projeto, a Formação Paraopeba é constituída sọbretudo por filitos quartzosos rítmicos e quartzitos. Mármores ocorrem esporadicamente, em lentes de dimensões restritas, intercaladas nos filitos.

A formação sobrepõe-se aos xistos Serra da Mesa, tendo sido observado que o contato é via de regra horizontalizado. Na porção sul da Folha Serra da Mesa, o contato é marcado por brechas e filões de quartzo leitoso, indicando ser o mesmo de natureza tectônica. O limite noroeste, especialmente na região do Córrego dos Pretos (Folha Trombas), é nitidamente por discordância: a direção geral dos epimetamorfitos é NW-SE, enquanto a dos xistos Serra da Mesa, na área, é E-W e NE-SW. Finalmente, na região do Patrimônio do Vicente, na porção central da Folha Serra da Mesa, o Grupo Bambuí é sobreposto pelo Grupo Serra da Mesa, através de falha de cavalgamento.

Estratigrafia A espessura da Formação Paraopeba, nas proximidades da Serra da Mesa, foi estimada em cerca de 800 a $1000 \mathrm{~m}$. Consiste em um quartzito basal, filito rítmico, filitos com lentes de mármore e quartzitos micáceos. Comparando-se com a estratigrafia estabelecida por Marini et al. (1976), na região ao norte da Serra da Mesa, depreende-se que a sequiência aflorante na área do Projeto Serra Dourada corresponde à porção inferior da Formação Paraopeba na região.

Quartzito fino É a camada basal da formação, possuindo aproximadamente $60 \mathrm{~m}$ de espessura. É constituído de quartzito de fino a médio, compacto, de cor branca a cinza-clara, com estratificação planoparalela pouco conspícua ou ocasionalmente estratificação cruzada de pequeno porte e marcas ondulares. Característica comum é a intensa brechação.

Filito rítmico Constitui uma camada com cerca de $600 \mathrm{~m}$ de espessura aparente. Na base, contém pequenas lentes de mármore, enquanto que, no topo, abundam finas intercalações de quartzitos. O filito é de coloração cinza (avermelhado, quando decomposto). Em geral é rítmico, com intercalações de camadas mais arenosas, o que facilita a identificação da estratificação, visto que a xistosidade é bem marcada. Próximo à base, o filito é por vezes grafitoso, como pode ser observado na Rodovia GO-29, ao norte de Campinaçu.

Filitos com lentes de mármore Formam uma camada com espessura estimada em cerca de $100 \mathrm{~m}$. Os filitos são semelhantes aos da unidade anterior, sendo porém localmente calcíferos, com lentes de mármore, que podem ocupar a espessura total da camada. As lentes de mármore são mais freqüentes entre os córregos dos Pretos e Ágúa Limpa (Folha Trombas) e próximo à Rodovia GO-29 (Folha Serra da Mesa). A rocha é cinza-clara, possui granulação fina e a estratificação é acentuada por minúsculas palhetas de muscovita. Estruturas estromatolíticas deformadas foram observadas na fazenda do Sr. Graciano, às margens da rodovia mencionada. 
Quartzitos micáceos Constituem a parte superior aflorante da Formação Paraopeba, na área. Sua espessura aparente mede cerca de $300 \mathrm{~m}$. São truncados por falha de cavalgamento, através da qual se lhes sobrepõem os xistos Serra da Mesa. Na base do pacote, ocorrem com freqüência muscovita-quartzo xistos, que passam para quartzitos muscovíticos e quartzitos puros em direção ao topo. A rocha é branca acinzentada, com granulação de fina a média, por vezes friável. Filões de quartzo leitoso são comuns.

Tectônica e Metamorfismo As camadas do Grupo Bambuí mostram-se anômalas, tanto sob o ponto de vista tectônico, quanto do metamorfismo, possuindo características de rochas de cinturões dobrados, evidenciando ter sido a Formação Paraopeba, na região, envolvida em ambiente miogeossinclinal, durante o Ciclo Brasiliano.

A disposição regional das camadas do Grupo Bambuí mostra nítida influência das estruturas dômicas das serras da Mesa e Dourada, indicando que estas se formaram, em parte, posteriormente à deposição desse grupo e mesmo às superfícies de cavalgamentos que ocorreram na região, uma vez que estas também se mostram onduladas. Esse fato pode ser constatado entre as serras da Mesa e Dourada (Folha Serra da Mesa), onde as direções e mergulhos dos metassedimentos Bambuí indicam a existência de uma bacia estrutural ou sinclinório. O mesmo ocorre com a superfície do cavalgamento que coloca o Grupo Serra da Mesa sobre o Grupo Bambuí, como pode ser depreendido do formato do traço da falha.

Os mergulhos do pacote geral do Bambuí são acentuados nas proximidades das estruturas dômicas e sub-horizontais, na porção citada, a meio caminho entre estas. A direção regional das camadas Bambuí é nordeste, infletindo para noroeste na região do Córrego dos Pretos, na Folha Trombas.

A estrutura local das camadas, devido a um forte amarrotamento interno, tem comportamento completamente diferente da estrutura regional. Mostra-se intensamente dobrada em isoclinais apertadas, com dimensões de poucos quilômetros, eixos mergulhando para noroeste e vergência nordeste. As dobras menores são perpendiculares em relação à macroestrutura, o que é explicado pela superimposição tardia dos domos, que moldaram a estrutura regional. Pelo menos duas outras fases do dobramento, menos conspícuas, podem ser observadas localmente nas rochas do Grupo Bambuí.

O metamorfismo dos metassedimentos Bambuí, na região, é o do fácies xisto-verde, com paragêneses que correspondem em geral à zona da clorita. Fenoblastos de biotita ocorrem associados a uma segunda fase de metamorfismo e dobramento.

CENOZÓICO As coberturas cenozóicas da área são restritas e localizadas. Limitam-se a finas capas detrito-lateríticas, geneticamente associadas à evolução das superfícies de aplainamento que afetaram, em três épocas distintas, a região. Aluviões quaternárias praticamente inexistem, restringindo-se ao leito do Rio Cana Brava.

\section{BIBLIOGRAFIA}

ALMEIDA, F. F. M. - 1967a - Observações sobre o Pré-Cambriano da Região Central de Goiás. Bol. Paran. Geoc., 26: 19-22, Curitiba

ALMEIDA, F. F. M. - 1968 - Evolução Tectônica do Centro-Oeste Brasileiro no Proterozóico Superior. An. Acad. Bras. Ciênc., 40, (suplemento): 285-295, Rio de Janeiro

ALMEIDA, F. F. M. - 1971 - Geochronological division of the Precambrian of South America. Rev. Bras. de Geoc., 1 (1): 13-21, São Paulo

ALMEIDA, F. F. M., HASUI, Y. e BRITO NEVES, B. B. - 1976 - The Upper Precambrian of South America. Inst. Geoc. USP. Bol. IG. v. 7: 45-80, São Paulo 
ALMEIDA, H. G. e SILVA, A. S. - 1972 - Projeto Serra Dourada. Geologia da Folha Ribeirão Corrente (c). Brasilia, UnB/DNPM (inédito)

ALMEIDA, V. J. - 1972 - Projeto Serra Dourada. Geologia da Folha de Mata Azul (b), Brasília, UnB/DNPM (inédito)

ANDRADE, J. M. L. e GONÇALVES, E. C. - 1972 - Projeto Serra Dourada, Geologia da Folha Ribeirão Corrente (b). Brasília, UnB/DNPM (inédito)

BARBOSA, O. - 1955 - Guia das Excursões do IX Gongresso da Sociedade Brasileira de Geólogia. Noticiário n. ${ }^{\circ}$, Sociedade Brasileira de Geologia, Rio de Janeiro

BARBOSA, O. - 1963 - Geologia Econômica e Aplicada a uma parte do Planalto Gentral Brasileiro. Rio de Janeiro, PROSPEG/DNPM (inédito)

BARBOSA, O., ANDRADE RAMOS, J. R., GOMES, F. A. e HELMBOLD, R. - 1966 - Geologia Estratigráfica, Estrutural e Econômica da Área do Projeto Araguaia. Rio de Janeiro, DNPM, DGM, Monogr. n. ${ }^{\circ} 19$

BARBOSA, O., BAPTISTA, M. B., DYER, R. G., BRAUN, O. P. G. e GOTTA, J. G. - 1969 Geologia e Inventário dos recursos minerais do Projeto Brasília. Rio de Janeiro, PROSPEC/DNPM (inédito)

BARbOSA, O., BAPTISTA, M. B., DYER, R. G. BRAUN, O. P. G., FRATIN, H., MENEGUESSO, G. - 1970 - Projeto Goiânia. Relatório Preliminar. Rio de Janeiro, PROSPEC/DNPM (inédito)

BARBOSA, O., BRAUN, O.P. G., DYER, R. G. e CUNHA, G. A. B. R. - 1970 - Geologia da Região do Triângulo Mineiro. Rio de Janeiro, DNPM, DFPM, Bol. 136, 200 pp.

BARREIRA, C. F. e BARBOSA, P.A.R. - 1972 - Projeto Serra Dourada. Geologia da Folha Mata Azul (d). Brasília, UnB/DNPM (inédito)

BARRETO FILHO, J. A. e VIANA, H. S. - 1972 - Projeto Serra Dourada, Geologia da Folha de Trombas (a). Brasília (inédito)

GAMPOS NETO, M. G. e FRÁGUAS, S. R. - 1972 - Projeto Serra Dourada. Geologia da Folha Dois de Junho (c). Brasília, UnB/DNPM (inédito)

COELho FIlHo, A. e PEREIRA, N. R. - 1972 - Projeto Serra Dourada. Geologia da Folha de Mata Azul (a). Brasília, UnB/DNPM (inédito)

COSTA, L. A. M. e ANGEIRAS, A.G. - 1971 - Geosynclinal evolution in the epi-Baykalian platform of Central Brazil. Geologische Rundschau, 60 (2): 1024-1 050, Stuttgart

COSTA, R. R. - 1972 - Projeto Serra Dourada. Geologia da Folha Serra da Mesa (a). Brasília, UnB/DNPM (inédito)

DARDENNE, M. A., ALMEIDA, H. G., ANDRADE, J. N. L., FERREIRA, J. A., GONÇALVES, E. G., PASSOS, H., RIBEIRO, G. G. e SILVA, A. S. - 1974 - Folha Ribeirão Corrente (SD-22-X-D-II-4-2), 1/50 000. Brasília, UnB/DNPM, Projeto Serra Dourada (inédito)

FARIA, A., ALMEIDA, V. J., BARBOSA, P. A. R., BARREIRA, G. P., COELHO FILHO, A., MORENO, J. J. P., PEREIRA, W. R., RABELO, L. G. R. - 1974 - Folha Mata Azul (SD-22-X-D-II-2), 1/50 000. Brasília, UnB/DNPM, Projeto Serra Dourada (inédito)

FERREIRA, J. A. - 1972 - Projeto Serra Dourada. Geologia da Folha de Ribeirão Corrente (a), Brasilia, UnB/DNPM, (inédito)

FUCK, R. A., BARRETO FILHO, J.A., HECHT, G., LARA FILHO, J., PEDROSO, A. C., SADECK, F. J., SOUZA, J. M., TRINDADE SOBRINHO, M. e VIANA, H. S. - $1974-$ Folha Trombas (SD-22-X-D-V-2), 1/50000. Brasília, UnB/DNPM, Projeto Serra Dourada (inédito)

HASUI, Y. e ALMEIDA, F. F. M. - 1970 - Geocronologia do Centro-Oeste Brasileiro. Soc. Bras. Geol., Bol. $19(1)$ : 5-26, São Paulo

LINDENMAYER, Z. G. - 1972 - Mapa Geológico do Estado de Goiás (1: 1000 000). Goiânia, DNPM, 6. ${ }^{\circ}$ Distrito/Centro-Oeste (inédito)

MARINI, O.J., BARBOSA, G. V., DARDENNE, M. A., FARIA, A. G., FUCK, A. - 1974a Projeto Serra Dourada: Relatório Final, 1, n. ${ }^{\circ}$, Brasília, UnB/DNPM (inédito)

MARINI, O. J., GAMPOS NETO, M. G., FRÁGUAS, S. R., SILVA, M. T. e VIEIRA, S. A. B. 1974c - Folha Dois de Junho (SD-22-X-D-III-3), 1/50000. Brasília, UnB/DNPM, Projeto Serra Dourada (inédito) 
MARINI, O. J., COSTA, R. R., FERREIRA, J. S. G., FERREIRA, M. C. B., SA, E. L., OLIVA, L. A. e TEIXEIRA NETO; A., - 1974b - Folha Serra da Mesa (SD-22-X-D-VI-1), 1/50 000. Brasília, UnB/DNPM, Projeto Serra Dourada (inédito)

MARINI, O.J., FUCK, R. A. e FIGUEIREDO, A. N. - 1976 - Projeto São Félix. Brasília, Convênio FUB/Eletronorte (inédito)

MATSUI, K., GIRARDI, V.A.V., BASEI, M. A. S. e HASUI, Y. - 1976 - Idades K/Ar do maciço básico-ultrabásico de Gana Brava, Goiás. 29. Congr. Bras. Geol., Resumos dos Trabalhos, p. 226, Belo Horizonte

MORENO, J. J. P. e RABELO, L. C. R., - 1972 - Projeto Serra Dourada. Geologia da Folha Mata Azul (c). Brasília, UnB/DNPM (inédito)

MILEWSKI, I. P., PAMPLONA, R., OSTRONOFF, C., SARMENTO, C. E. M. - $1970-$ Excursão n. ${ }^{\circ}$ 7, Região de Cana Brava. XXIV Congr. Bras. de Geol., Boletim Especial n. ${ }^{\circ}$ 2, Brasília

PEDROSO, A. G. e TRINDADE SOBRINHO, M. - 1972 - Projeto Serra Dourada. Folha Trombas (c). Brasília, UnB/DNPM (inédito)

RIBEIRO, G. C. e PASSOS, H. - 1972 - Projeto Serra Dourada. Geologia da Folha Ribeirão Corrente (d). Brasília, UnB/DNPM (inédito)

SÁ, E. L. e OLIVA, L. A. - 1972 - Projeto Serra Dourada. Folha Serra da Mesa (d). Brasília, UnB/DNPM (inédito)

SADECK, F. J. e HECHT, C. - 1972 - Projeto Serra Dourada. Geologia da Folha Trombas (d). Brasília, UnB/DNPM (inédito)

SANTIAGO, A. F. e FERREIRA, J. S. - 1972 - Projeto Serra Dourada. Geologia da Folha Serra da Mesa (b). Brasília, UnB/DNPM (inédito)

SCHOBBENHAUS FILHO, G., RIBEIRO, C. L., OLIVA, L. A., TAKANOHASHI, J. T., LINDENMAYER, Z. G., VASCONGELOS, J.B. e ORLANDI, V. - 1975 - Carta Geológica do Brasil ao Milionésimo. Folha Goiás (SD-22). Brasília, DNPM, $114 \mathrm{pp}$.

SIlva, M. T. e VIEIRA, S. A. B. - 1972 - Projeto Serra Dourada. Folha Dois de Junho (d). Brasília, UnB/DNPM (inédito)

SOUZA, A. - 1973 - Geologia e Geocronologia do Complexo Barro Alto, Goiás. Tese de Doutoramento, FFCL de Rio Glaro, S.P. (inédito)

SOUZA, J. M. e LARA FILHO, J. - 1972 - Projeto Serra Dourada. Geologia da Folha Trombas (b). Brasília, UnB/DNPM (inédito)

STREGKEISEN, A. L. - 1967 - Classification and nomenclature of Igneous Rocks., N. Jb. Miner. 107, Berlim, 1967

TEIXEIRA NETO, A. Q. e FERREIRA, M. G. B. - 1972 - Projeto Serra Dourada. Folha Serra da Mesa (c). Brasília, UnB/DNPM (inédito) 